\title{
THE PRIVATE BUSINESS DURING THE NEW ECONOMIC POLICY (ON THE MATERIALS OF THE VOLGA REGION)
}

\author{
Sergey V. Vinogradov \\ Astrakhan State University, Astrakhan, Russian Federation \\ Yuliya G. Eshchenko \\ Astrakhan State University, Astrakhan, Russian Federation \\ Nataliya I. Kulakova \\ Astrakhan State University, Astrakhan, Russian Federation
}

\begin{abstract}
The development of the private business had the regional features in the Volga region during the new economic policy. The originality of the study lies in the fact that it is conducted on the example of a large Russian region - the Volga region. The work is based on the documents of the regional archives of the Volga towns and on the materials of the local press.

In the 1920s the private business was an integral part of the Russian multistructural economy, formed under the influence of natural and historical factors of its development. The attempt of the Bolsheviks to failure of the multistructure in economic during the policy of "military communism"; the prohibition of freedom in the trade and in business; the introduction of the surplus appropriation system - all these became the reasons of the political and economic crisis of the end of 1920s. At this time a considerable mass of peasants and working people revolted. The return to multistructural economy became important achievement of the new economic policy, which contributed to restoration of the destroyed economy.

The private business has developed significantly in the trade, grain procurement and the fishing industry in the Volga region. In these spheres of economic activity was a competitive struggle between state, cooperative and private companies. The state had to strengthen organizations working in these spheres, responding to the economic challenge from private capital in trade, grain companies and the fishing industry. A special interest was placed on the revival of cooperation. State and cooperative companies were strengthened by experienced personnel, supplied with scarce goods. They were granted loans on preferential terms. The result of the competition was a rapid recovery of these sectors of the economy, significantly outpacing the overall development of the regional economy. $\stackrel{\circ}{\circ}$ In winning from the competition were also ordinary citizens - consumers who could receive quality goods and services at cheap prices.
\end{abstract}

Key words: private business, new economic policy, Volga region, Stalingrad, Saratov, Astrakhan, fish industry.

Citation. Vinogradov S.V., Eshchenko Yu.G., Kulakova N.I. The Private Business During the New Economic Policy (on the Materials of the Volga Region). Vestnik Volgogradskogo gosudarstvennogo universiteta. Serija 4, Istorija. Regionovedenie. Mezhdunarodnye otnoshenija [Science Journal of Volgograd State University. History. Area Studies. International Relations], 2017, vol. 22, no. 4, pp. 139-150. (in Russian). DOI: https://doi.org/ 10.15688/jvolsu4.2017.4.13

\section{ЧАСТНОЕ ПРЕДПРИНИМАТЕЛЬСТВО В ПЕРИОД НЭПА (НА МАТЕРИАЛАХ ПОВОЛЖЬЯ)}

\section{Сергей Вадимович Виноградов}

Астраханский государственный университет, г. Астрахань, Российская Федерация 


\section{Юлия Геннадьевна Ещенко}

Астраханский государственный университет, г. Астрахань, Российская Федерация

\section{Наталия Игоревна Кулакова}

Астраханский государственный университет, г. Астрахань, Российская Федерация

Аннотация. Цель статьи, заключающаяся в выявлении региональных особенностей функционирования частного предпринимательства в Поволжье, была достигнута путем исследования развития ряда ключевых отраслей хозяйственной деятельности региона. В их числе рыбная промышленность, торговля, хлебозаготовительные компании. В статье показываются региональные особенности развития предпринимательства в период новой экономической политики. Оригинальность исследования заключается в том, что оно проведено на примере крупного региона страны - Поволжья. Работа построена в основном на документах областных архивов поволжских городов и материалах местной прессы.

Анализ источников и их интерпретация, подготовка текста соответствующего раздела статьи в рамках единой концепции работы осуществлялись самостоятельно каждым автором (торговля - Н.И. Кулакова, хлебозаготовительные компании - Ю.Г. Ещенко, рыбная промышленность - С.В. Виноградов). Также Виноградовым С.В. была проведена окончательная обработка статьи на предмет сохранения стилистического и смыслового единства текста перед его подачей для публикации.

Частное предпринимательство в 1920-е гг. являлось составной частью многоукладной экономики страны, естественно сложившейся под влиянием природных и исторических факторов ее развития. Попытка большевиков отказаться от многоукладности, проводимая в русле политики «военного коммунизма», наряду с запрещением свободы торговли и предпринимательства, а также введение продразверстки стали причинами политического и экономического кризиса конца 1920 г., когда против власти поднялась значительная масса крестьянства и часть рабочего класса. Возврат к многоукладности, наряду с гражданским миром и свободой предпринимательства (хоть и урезанной), стали важными достижениями новой экономической политики, способствовавшими скорому восстановлению разрушенного хозяйства.

В Поволжье частное предпринимательство получило значительное развитие в торговле, хлебозаготовках и рыбной промышленности. Именно в этих сферах хозяйственной деятельности развернулась жесткая конкурентная борьба между государственными, кооперативными и частными предприятиями. Отвечая на экономический вызов со стороны частного капитала в торговле, хлебозаготовительных компаниях и рыбной промышленности, государство вынуждено было укреплять свои организации, работавшие в этих сферах. Особая ставка делалась на возрождение кооперации. Государственные и кооперативные предприятия укреплялись опытными кадрами, снабжались дефицитными товарами, им предоставлялись кредиты на льготных условиях. Результатом конкуренции стало быстрое восстановление вышеперечисленных отраслей хозяйства, заметно опережавшее общее развитие региональной экономики. В выигрыше от конкурентной борьбы были также рядовые граждане - потребители, которые могли получать качественные товары и услуги по дешевым ценам.

Ключевые слова: частное предпринимательство, новая экономическая политика, Поволжье, Сталинград, Саратов, Астрахань, рыбная промышленность.

Цитирование. Виноградов С. В., Ещенко Ю. Г., Кулакова Н. И. Частное предпринимательство в период нэпа (на материалах Поволжья) // Вестник Волгоградского государственного университета. Серия 4, История. Регионоведение. Международные отношения. - 2017. - Т. 22, № 4. - С. 139-150. - DOI: https://doi.org/ 10.15688/jvolsu4.2017.4.13

При значительном исследовательском интересе к новой экономической политике многие стороны этого яркого периода освещены недостаточно. Это особенно актуально для региональной истории нэпа. А именно в ней таится ценный опыт решения хозяйственных проблем, который мог бы быть интересным в настоящее время. Не все же наступать на старые грабли... В данной статье хотелось бы познакомить читателя с некоторыми ре- зультатами изучения истории 1920 -х гг. в крупном регионе страны - в Поволжье. Работа построена в основном на материалах областных архивов городов Поволжья и материалах местной печати.

Решение о замене экономической модели и введении новой экономической политики было принято на Х съезде РКП(б), в марте 1921 года. Это был пик сложного политического и экономического кризиса, разразив- 
шегося осенью 1920 г. и ставшего неожиданностью для руководства РКП(б) [17, с. $68-$ 86]. Казалось бы, своей победой в гражданской войне над бывшими правящими классами большевики доказали необходимость отстаиваемых ими идей о скором переходе к коммунистическому обществу. В том числе под этим подразумевался слом вековых устоев экономической жизни, таких как многоукладность, товаро-денежные отношения, рынок и т. д. Частично подобные идеи воплощались в жизнь в процессе реализации в 1918-1920 гг. политики военного коммунизма. Именно продолжение этой политики после окончания гражданской войны стало причиной резкого недовольства крестьянства и части городского населения, в том числе и рабочего класса [18].

Новая экономическая политика стала ответом высшего руководства РКП(б) во главе c В.И. Лениным на угрозу нового витка гражданской войны и потерю власти. Оно позволило снизить накал крестьянских возмущений и в конечном итоге спасло страну от новых кровопролитий. Нэп более соответствовала устоям хозяйственной жизни России.

Возвращение к гражданскому миру и естественной многоукладности экономики, где сочетались бы государственное планирование и рынок, стали главными достижениями нового курса. Именно они позволили добиться быстро ощутимого эффекта в деле восстановления промышленности и сельского хозяйства в первой половине 1920-х годов. Причем за счет народной предпринимательской инициативы многие проблемы, еще вчера казавшиеся неразрешимыми, решались быстро, как бы сами собой. «Легко можно представить себе, как экономисты и политические руководители Советского Союза в начале 20-х гг. задавали друг другу вопрос, прозвучавший из уст Пола Самуэльсона в 50-е гг. в Америке: "Как же нам удалось это сделать?"» [37, с. 217].

В Поволжье предпринимательская активность наиболее значимо проявила себя в торговле, на хлебозаготовительном рынке и в рыбной промышленности.

Торговля. В Поволжье в 1923 г. частный торговый капитал контролировал $94 \%$ розничной и приблизительно $50 \%$ оптовой торговли $[9$, с. $38 ; 11$, с. 46-47]. Частная тор- говля стала важным связующим звеном между городской промышленностью и индивидуальным крестьянским хозяйством. Понимание рыночной конъюнктуры, хорошая подготовка продавцов, предприимчивость обеспечивали высокую эффективность и конкурентоспособность частных торговых предприятий.

Документы по проверкам государственных и кооперативных торговых организаций констатировали, что, как правило, их управленческий аппарат был неоправданно раздут. Частыми были случаи злоупотреблений со стороны сотрудников этих организаций [24, л. $6 ; 25$, л. 19]. Нередко в ассортиментах товаров государственных магазинов и кооперативных лавок находился товар, не пользовавшийся спросом, продавцы были некомпетентны, нерасторопны, всячески выказывали незаинтересованность в результатах своей работы. «На Трусовском поселке в 10 шагах друг от друга расположены 2 бакалейных лавки ЦРК. Они открываются только в зависимости от настроения приказчиков, которые халатно относятся к пополнению своего ассортимента. В лавках очень много ненужного товара» [12].

Участники XVII Саратовской губернской партийной конференции обращали внимание в своих докладах на тот факт, что время торговли у нэпмана не регламентировалось, тогда как в госторговле и в кооперации «оно было загнано в рамки трудового кодекса» [32, л. 119]. Тем самым косвенно признавалось, что торговля является той сферой, где излишняя регламентация в государственных и кооперативных торговых предприятиях вредит в конкурентной борьбе с частником.

В государственных магазинах и кооперативных лавках для покупки товара надо было пройти несколько инстанций: касса, продавец, выдача товара и т. д. У частного торговца покупатель сразу обслуживался, без лишних инстанций. К тому же у частника всегда была сдача на крупные купюры, он давал товар в долг, с ним можно было поторговаться, да и просто поговорить, обсудить волнующие проблемы [26, л. 138].

«На данной стадии развития госторговля ведет дела хуже частной торговли и для нее наиболее актуальным вопросом является 
пока сокращение издержек хотя бы до уровня частной торговли» - констатировал известный в то время партийный экономист, автор концепции «первоначального социалистического накопления» Е. Преображенский [20, с. 78]. К похожим выводам приходили авторы астраханского экономического журнала «Наш край» $[13 ; 14 ; 22 ; 28]$.

Однако, несмотря на жалобы со стороны партийных функционеров и государственных чиновников, конкуренция в торговле благоприятным образом сказывалась на ее работе. Работники государственной и особенно кооперативной торговли вынуждены были перенимать многие приемы работы у частника, выражаясь словами В.И. Ленина, «учиться торговать». Но в результате этой конкуренции в выигрыше оказался рядовой потребитель. Рынок быстро наполнился самыми разнообразными товарами и услугами. Цены на основные товары в 1920-е гг. оставались стабильными и даже постепенно снижались, как это произошло с ценами на мясо в Астрахани в 1924 году [6]. К тому же полки, заполненные хорошим товаром магазинов, при широком развитии сдельной формы оплаты труда на предприятиях государственной промышленности являлись хорошим стимулом к повышению производительности труда для рабочих государственных заводов и фабрик, обедневших за предыдушие годы.

Хлебозаготовительный рынок. С торговлей тесно был связан хлебозаготовительный рынок. С середины 1920-х гг. каждая хлебозаготовительная кампания становилась полем жесткой конкуренции между государством и частными предпринимателями. Что, впрочем, было не удивительно, ведь речь шла об основном экспортном товаре страны.

В условиях окончания восстановления промышленности партийно-государственное руководство СССР рассчитывало средства, вырученные от продажи зерна за рубежом, направлять на разворачивавшуюся индустриализацию. Окрепшие с начала нэпа частные хлебозаготовительные фирмы, в союзе с зажиточным крестьянством, не хотели уступать этот рынок. Первый раунд борьбы - хлебозаготовительная компания осени 1925 г. [5, c. 376-380] - остался за частниками. Правительственные планы по закупке промышлен- ного оборудования для строившихся предприятий были сорваны, ибо государственным организациям не удалось собрать нужного количества зерна для выполнения уже заключенных с иностранцами контрактов. Компания 1925 г. показала силу и возможности частных хлебозаготовителей. Наркомат внутренней торговли СССР, в справке для Госплана, вынужден был признать недооценку их возможностей [7, л. 85-86].

В конкурентной борьбе с частным капиталом в середине 1920-х гг. государственные и кооперативные заготовительные организации заметно уступали. Например, в Ульяновской губернии в 1924 г. частные заготовители приобрели такое же количество зерна, что и государственные и кооперативные организации. В Царицынской губернии, с железнодорожных станций Камышин и Кандауровка, нэпманы сумели отправить больше зерна, чем государственные кооперативные заготовители [30, л. 47-48]. Важным показателем мощи и влияния частных хлебозаготовителей в Саратовской губернии в середине 1920-х гг. была аренда ими «лучших мельниц по самым высоким государственным расценкам» [34, л. 138].

В основу эффективной работы частных хлебозаготовительных фирм был заложен ряд факторов. Во-первых, имелся значительный, еще дореволюционный опыт ведения этого нелегкого дела, нацеленность на получение значительной прибыли. Практически все нэпманы 1920-х гг., работавшие на зерновом рынке, занимались этим бизнесом не в первом поколении. Новая экономическая политика позволила этим предприимчивым и талантливым людям вновь восстановить привычное дело. Например, в 1925 г. в Саратовской губернии закупками зерна занималось 16 крупных частных хлебозаготовителей. Первыми среди них были Безбородовы и Синевы - представители известных еще с XIX в. купеческих династий из г. Балашова (крупного в Поволжье центра хлебной торговли). Капитал, например Синевых, в середине 1920-х гг. составлял не менее 500000 руб. - значительная по тем временам сумма [31, л. 43].

Во-вторых, частные заготовители имели обширные торговые связи по всей стране, наработанные также с дореволюционного пе- 
риода. Это позволяло им оперативно, без особых препятствий вывозить зерно. Например, частные хлебозаготовители имели приемные пункты во многих уездах Саратовской и Сталинградской губерний. Шатухин, хлеботорговец из Казани, перерабатывал приобретенное в поволжских губерниях зерно на мельнице в г. Вольске, а затем переправлял муку баржами на продажу в Москву, Нижний Новгород и Казань. Помимо крупных хлебозаготовителей на рынке функционировало много мелких торговцев с капиталом от 3000 до 15000 рублей [30, л. 59-61].

В-третьих, у частных предпринимателей закупочная цена была в среднем на 30 \% больше, чем у государства, поэтому крестьяне (и не только зажиточные), стремившиеся от собранного урожая получить максимальную прибыль, охотнее имели дела с ними, чем с государственными заготовителями.

B-четвертых, у частных предпринимателей организация ведения дела была поставлена намного лучше, чем у их государственных конкурентов. Аппарат частной хлебозаготовительной фирмы, как правило, обладая значительной мобильностью и эффективностью, был минимален по числу работников. Тогда как штаты государственных и кооперативных организаций раздувались, как правило, родственниками руководителей, весьма далекими от хлебозаготовительного дела, но стремящимися занять «хлебное место» [31, л. 40]. Какая уж в таких условиях могла быть конкуренция с частником! К тому же государственные и кооперативные заготовители часто конкурировали между собой, распыляя силы.

В-пятых, частные хлебозаготовители успешно применяли против своих конкурентов такие методы, как «экономический шпионаж». Они засылали на работу в государственные и кооперативные конторы «своих агентов», либо подкупали сотрудников этих организаций, получая, таким образом, сведения об их планах [30, л. 59-61].

В-шестых, государственные и кооперативные заготовители нередко шли на организацию различных афер и воровство средств, нанося серьезный урон государственным интересам и теряя авторитет среди крестьянства [30, л. 59-61].
В такой ситуации обоснованными выглядят требования партийных и государственных руководителей различных уровней навести порядок в хлебозаготовках. В этом отношении весьма показательно решение Пленума Самарского губкома РКП(б), подводившего итоги компании 1925 года. Он потребовал обеспечить согласованность в действиях государственных и кооперативных организаций. Также было рекомендовано навести порядок в деятельности организаций, отвечавших за снабжение деревни промышленными товарами. Помимо этого в резолюции Пленума было записано, что Самарский губком РКП(б) выступает за использование административных мер с целью ограничения деятельности частного капитала на хлебозаготовительном рынке и для наведения порядка в этом вопросе [27, л. 8].

$\mathrm{B}$ рамках реализации этого решения $\mathrm{Ca}$ марский губвнуторг в январе 1926 г. предупредил руководителей государственных хлебозаготовительных организаций о строгой ответственности за поддержку частных скупщиков зерна. Им с 1926 г. также стали чаще отказывать в кредите. Вагоны и баржи на транспорте, а также мельницы для изготовления муки им теперь предоставлялись только после выполнения всех заявок государственных и кооперативных организаций $[24$, л. 6].

В сводках информотдела ЦК РКП(б) за 1925 г. отмечалось, что ряд губкомов Поволжья (в том числе Ульяновский) ставили перед ЦК РКП(б) вопрос об ограничении деятельности частных хлебозаготовитей [29, л. 40-41, 44-47]. Нарком внутренней торговли СССР А.И. Микоян в письме поволжским губвнутторгам «О директивных ценах для Поволжья» от 31 августа 1927 г. также заострял внимание местных партийных руководителей на активизацию работы по снижению заготовительных цен «в желательном для государства направлении» [35, л. 27].

Еще одним следствием хлебозаготовительного кризиса 1925 г. стало наведение порядка на транспорте. До 1926 г. нэпманы вне очереди, за определенную мзду, переправляли урожай в любую точку Советского Союза. А вот государственное зерно месяцами портилось на тех же железнодорожных станциях и речных пристанях. С 1926 г. услуги железнодорожного и речного транспорта стали пре- 
доставляться частным заготовителям в последнюю очередь.

Таким образом, государство с 1926 г. «железной рукой» стало возвращать свое влияние на зерновом рынке. Как уже отмечалось выше, это было связано с тем, что зерно являлось основным экспортным товаром. Его продажа на зарубежных рынках должна была обеспечить возрождавшуюся промышленность новой техникой и технологиями. Жесткие меры по отношению к частным хлебозаготовителям быстро стали давать результаты. Доля частных заготовителей зерна с осени 1926 г. стала быстро снижаться, а в 1928 г. частный капитал практически был вытеснен с рынка хлебозаготовок. И все же в первой половине 1920-х гг. частное предпринимательство на зерновом рынке сыграло положительную роль, способствуя возрождению крестьянского хозяйства и обеспечению хлебом городского населения.

Рыбная промышленность. К началу XX в. Астраханская губерния являлась крупнейшим центром по добыче и переработке рыбы в России. В устье Волги люди с давних пор добывали рыбу, постепенно осваивая технологии переработки, сохранения и доставки этого скоропортящегося товара в другие регионы. Частная инициатива, удачливость и предприимчивость всегда были важными составляющими развития рыбного промысла в Волго-Каспийском рыболовном районе. В период «военного коммунизма» рыбная промышленность была национализирована и объединена под управлением государственного главка: «Областьрыба». Причем этой монополии Правительство придавало особое значение [4]. Она была сохранена даже после введения нэпа, вплоть до 1924 г., несмотря на упадок рыбной промышленности и ежегодное снижение улова рыбы [8].

После отмены государственной монополии частный капитал стал быстро восстанавливать утраченные позиции в отрасли. Как в торговле и хлебозаготовках, бурный рост частных организаций происходил благодаря хорошему знанию дела, стремлению к высоким прибылям, мобильности. По товарообороту частные рыбопромышленники значительно превосходили конкурентов. У государственных и кооперативных организаций в рыбной отрасли в 1920-е гг. «капитал оборачивался не больше 6 раз в год, а у частника - 10 раз и больше» [23, л. 60].

Газета «Коммунист» в статье «Началась путина» так описывала частных скупщиков рыбы: «При подходе к Каспию все чаще стали встречаться суда, буксировавшие в Астрахань по нескольку рыбниц. ...Это были частные скупщики рыбы. Множество их в начале путины отправляются на речной простор или на взморье. Там они снабжают ловцов нужным товаром: нужна соль - найдут ее, нужен лед - пожалуйста. Им надо, чтобы ловцы вовремя расплачивались. Для них важно, чтобы были деньги, а владеть ими и оборачивать их с невероятной быстротой они прекрасно умеют. И там, где госторговля или кооператив терпят убытки, частные скупщики всегда имеют барыш» [33].

Частные предприниматели применяли разнообразные возможности для активизации своей деятельности. «Банки Астрахани в 1925 г. предоставили частникам 3428000 р. кредита, при среднем сроке их погашения 45 суток, что было выгодно последним. Несмотря на рекомендации партийных органов государственные и кооперативные организации, в погоне за прибылью, кредитовали на льготных условиях частных рыбопромышленников, в частности под предлогом “необходимости сбыта тех товаров, которые сами эти организации сбыть якобы не могли". Общая сумма такого кредитования в 1925 г. составила 1145000 р. [22, с. 30]. Вкладывали предприниматели в дело и собственный капитал. В том же 1925 г. частные рыбопромышленники фактически вложили в отрасль собственных средств на сумму 7120000 р.» [22, с. 31]. По данным «Бюллетеня рыбной промышленности» доля частных рыбопромышленных фирм в общем улове астраханской рыбной промышленности после отмены государственной монополии росла значительными темпами:

\begin{tabular}{|l|c|c|c|}
\hline & 1923 & 1924 & 1925 \\
\hline Госорганы, \% & 82,5 & 68,0 & 51,8 \\
\hline Кооперация, \% & 13,1 & 14,7 & 23,6 \\
\hline Частный капитал, \% & 3,8 & 17,7 & 34,6 \\
\hline
\end{tabular}

В 1927 г. частные рыбопромышленные фирмы в Астрахани имели следующую при- 
быль на вложенный капитал $[19$, с. 15]: Товарищество «Рыбник» - $307 \%$; Братья Солдатовы - $400 \%$; Братья Заславские - $455 \%$; Маячное товарищество - $400 \%$.

С доходов частные рыбопромышленники платили по повышенной ставке государственные и местные налоги. Так, фирма братьев Солдатовых из 133000 руб. прибыли в 1927 г. отчислила в налог 94000 рублей [19, с. 15].

Успешное развитие частного предпринимательства в рыбной промышленности и конкуренция с кооперативными и государственными предприятиями способствовали быстрому восстановлению отрасли и росту добычи рыбы. В 1926 г. (через два года после отмены государственной монополии) астраханская рыбная промышленность по уловам достигла довоенного уровня [21, л. 85]. В выигрыше опять-таки оказались граждане страны, которые по недорогим ценам стабильно могли получать вкусную и полезную рыбную продукцию. Особенно это было значимым для Поволжья, сельское хозяйство которого в первой половине 1920-х гг. восстанавливалось от засухи и голода 1921 года [1, с. 36].

О нэпманах 1920-х гг. сохранились достаточно скудные сведения. Пресса тех лет писала о них необъективно, карикатурно, замалчивая положительное и выпячивая недостатки. В архивах уцелели лишь обрывочные данные о налогообложении частных предприятий или анкеты, в которых упоминается только вид деятельности и юридический адрес. По таким скупым сведениям довольно непросто рассмотреть индивидуальные черты характера и уж тем более проследить жизненный путь этих людей.

В то время как некоторые известные российские экономисты, осевшие в эмиграции, предсказывали скорое падение «коммунистической диктатуры», которая, по их мнению, должна раствориться в рыночной стихии нэпа [16], многие нэпманы отдавали себе ясный отчет, что их деятельность не может продолжаться долго [3; $15 ; 36]$. Им приходилось работать в условиях жесткого экономического и политического давления со стороны государства. Мы практически не знаем их лиц: если фотографии и сохранились, то лишь в семейных архивах потомков. Вот почему сведения приходится собирать по крупицам, а воссоздать полноценные биографии практически невозможно.

Астраханский историк Д.К. Батрашев на основе многолетних исследований государственных и семейных архивов создал следующий обобщенный образ астраханского рыбопромышленника-нэпмана, который разнится с тем стереотипом, который был нарисован советской прессой 1920-х гг., а затем растиражирован кинематографом: «Его средний возраст составлял 43 года. В основном частной предпринимательской деятельностью занимались зрелые люди, имевшие большой жизненный опыт и обладавшие практическими навыками, от 40 до 60 лет. Впрочем, около $20 \%$ из них не достигли 35 лет. Так, предпринимателю Павлу Кузнечикову было 27 лет, Натану Блоху - 29, Эмилю Кантеру и Самуилу Фраткину - по 26. Многие являлись коренными астраханцами, но встречались и переселенцы из Пензы, Смоленска, Украины, Кавказа, Сибири и даже Дальнего Востока. Как свидетельствуют данные анкет, более 60 \% предпринимателей родились в городе, получили домашнее образование. Хотя среди них были и лица, закончившие ремесленные училища. До 1917 г. многие имели небольшое собственное дело либо работали приказчиками, помощниками или служащими по найму у крупных купцов и промышленников. Были также выходцы из рабочих, крестьян, мелких индивидуальных ремесленников. По нашим подсчетам, около $14 \%$ астраханских предпринимателей служили в прошлом в канцеляриях либо занимались свободной деятельностью. Основная часть этих людей приобщилась к предпринимательской деятельности только после начала нэпа» [2].

Изучение экономической истории Поволжья показывает, что несмотря на свои незначительные размеры в общем объеме советской экономики 1920-х гг., частный промышленный капитал обладал высокой эффективностью и мощным созидательным потенциалом. Работая на рыночного потребителя, он дополнял своей продукцией небогатый ассортимент государственной промышленности. В условиях товарного голода частная индустрия выполняла общественно-полезные функции, способствуя развитию производительных сил страны и укреплению «смычки». 
С 1927 г. руководство СССР взяло курс на вытеснение частнокапиталистических элементов из экономики страны. Но в ряде регионов, в том числе в Астрахани, частнокапиталистический уклад продолжал развиваться и даже укреплял свои позиции, а решения центральных партийных и государственных органов об ограничении его деятельности саботировались местной властью. Удельный вес частных предприятий в рыбной промышленности Астраханского округа (с мая 1928 г. территория бывшей Астраханской губернии на правах округа вошла в состав Нижневолжского края с центром в Саратове) доходил в 1928 г. до 44,6 \% [2]. Потребовалось репрессивное вмешательство союзных органов, чтобы привести рыбную отрасль к общему знаменателю с экономикой страны. Впоследствии события весны лета 1929 г. получили название «Астраханщина». Это был один из самых крупных процессов над предпринимателями и коррумпированными чиновниками, положивших конец новой экономической политике. К судебной ответственности по процессу было привлечено 129 человек - чиновников различного уровня и частных предпринимателей, из них 14 человек были приговорены к высшей мере, более 1250 человек были уволены с работы [15, с. 63, 70-71]. Основными обвинениями были: взяточничество, моральное разложение советских служащих.

«Астраханщина» - это противоречивое и многосложное явление истории 1920-х годов. Исследование материалов этого дела показывает, что, с одной стороны, оно было искусственно раздуто, для того, чтобы покончить с деятельностью частного капитала в рыбной отрасли, пустившего там глубокие корни. Отсюда мощное пропагандистское обеспечение процесса, привлечение известных писателей (И. Ильф, Е. Петров), журналистов (М. Кольцов), поэтов (В. Маяковский), подключение союзных органов власти, показная суровость наказания. Но, с другой стороны, суд беспристрастно вскрыл многочисленные случаи коррупции и морального разложения среди астраханского чиновничества, в том числе членов ВКП(б) [15, с. 63-72]. Схожие события - весной 1928 г. произошли в Смоленске (так называемый «Смоленский нарыв»).
Предлог для «вскрытия нарыва» был все тот же - коррупция среди работников государственного аппарата, происходившая на фоне роста кулачества в губернии [10].

Таким образом, в конце 1920-х гг. репрессиям подвергались те регионы, где нэп пустил крепкие корни, и рост частного предпринимательства шел вопреки курсу партийно-государственного руководства СССР на его свертывание. Шахтинское дело, судебные процессы в Смоленске в 1928 г. и в Астрахани в 1929 г. фактически подвели черту под дальнейшим развитием новой экономической политики.

\section{СПИСОК ЛИТЕРАТУРЫ}

1. Баскин, Г. И. Современная дифференциация и современные типы крестьянских хозяйств / Г. И. Баскин // Вестник Среднего Поволжья. Самара, 1926. - № 1. - С. 9-47.

2. Батрашев, Д. К. Частное предпринимательство в годы новой экономической политики в Астраханской губернии (округе) в 1921-1929 гг. / Д. К. Батрашев // Альтернативы большевистской модернизации в годы новой экономической политики. - М. : АНО НИИ «Истории, экономики и права», 2014. - С. 77-93.

3. Валентинов, Н. (Вольский Н.). Новая экономическая политика и кризис партии после смерти Ленина. Годы работы в ВСНХ во время НЭП. Воспоминания / Н. Валентинов. - М. : Современник, 1991. - $367 \mathrm{c}$.

4. Декрет Совета народных комиссаров РСФСР. 31 мая 1921. «О рыбной промышленности и рыболовстве» // Музей истории Российских реформ имени П.А. Столыпина. - Электрон. текстовые дан. - Режим доступа: http://музейреформ.pф/ node/13795 (дата обращения: 14.03.2017). - Загл. с экрана.

5. Жуков, Ю. Оборотная сторона НЭПа. Экономика и политическая борьба в СССР. 1923-1925 гг. / Ю. Жуков - М. : ИЦ «Аква-Терм», 2014. - 448 с.

6. Зенченко, Т. Мясной рынок Астраханской губернии / Т. Зенченко // Наш край. - Астрахань, 1925. - № 3. - C. 61-72.

7. Информационная справка Наркомата внугренней торговли СССР от 10 ноября, 1925 // Российский государственный архив экономики (РГАЭ). Ф. 4372. - Оп. 12. - Д. 19.

8. Кисилевич, К. С. К вопросу о восстановлении ловецкого хозяйства / К. С. Кисилевич // Наш край. - Астрахань, 1924. - № 1. -С. 15-52. 
9. Коган, Г. А. Бюджет саратовского рабочего / Г. А. Коган // Нижнее Поволжье. - Саратов, 1924. № 1. - С. 35-40.

10. Кодин, Е. В. «Смоленский нарыв» / Е. В. Кодин. - Смоленск : Изд-во СГПИ, 1995. - 112 с.

11. Кочаков, А. Ф. Потребительская кооперация в Самарской губернии / А. Ф. Кочаков // Вестник Среднего Поволжья. - Самара, 1925. - № 4. C. $46-47$.

12. Ландриков, Г. «Горе-кооператоры» / Г. Ландриков // Коммунист. - Астрахань, 1926. - 12 окт.

13. Ларионов, А. Динамика торговых предприятий за 1923/24 и 1924/25 хозяйственный год в Астраханской губернии по данным промналога / А. Ларионов // Наш край. - Астрахань, 1926. № 9-10. - С. 32-38.

14. Лупикин, В. И. Торговля. Обзор за 1922/ 23 хозяйственный год / В. И. Лупикин // Наш край. Астрахань, 1924. - № 2. - С. 72-91.

15. На южном форпосте России. Из истории Управления Федеральной службы безопасности РФ по Астраханской области. 1918-2000 гг.: Документы. Материалы. Воспоминания / под ред. В. Н. Папсуева. - Волгоград : Изд-во «Станица-2», 2000. $-321 \mathrm{c}$.

16. НЭП: взгляд со стороны. - М. : Московский рабочий, 1991. - 303 с.

17. Павлюченков, С. А. «Орден меченосцев»: партия и власть после революции. $1917-$ 1929 / С. А. Павлюченков. - М. : Собрание, 2008. $463 \mathrm{c}$.

18. Павлюченков, С. А. С чего начинался нэп / С. А. Павлюченков // Трудные вопросы истории : сб. ст. - М. : Политиздат, 1991. - С. 45-61.

19. Потяев, А. И. Волго-Каспийская рыбная промышленность / А. И. Потяев // Бюллетень рыбного хозяйства. - 1928. - № 11. - С. 15.

20. Преображенский, Е. Основной закон социалистического накопления / Е. Преображенский // Пути развития: дискуссии 1920-х гг. : сб. ст. - Л. : Лениздат, 1990. - С. 53-131.

21. XV Астраханская Губернская конференция ВКП(б). 26-27 ноября, 1926 // Государственный архив современной документации Астраханской области (ГАСД АО). - Ф. 1. - Оп. 1. - Д. 172.

22. Разин, А. Частный капитал в товарообороте и промышленности Астраханской губернии / А. Разин // Наш край. - Астрахань, 1926. - № 8. C. 24-33.

23. Резолюция Бюро Астраханского губкома РКП(б) «Об итогах весенней путины». 8 июня, 1925 // ГАСД АО. - Ф. 1. - ОП. 1. - Д. 176.

24. Резолюция Бюро Самарского губкома РКП(б) «О хлебозаготовках». 21 января, 1926 // Центр документации новейшей истории Самарской области (ЦДНИСО). - Ф. П-1. - Оп. 1. - Д. 1869.
25. Резолюция Бюро Саратовского губкома РКП(б) «Итоги выборов сельских советов». 22 декабря, 1924 // ГАНИСО. - Ф. 27. - Оп. 1. - Д. 101.

26. Резолюция Бюро Саратовского губкома РКП(б) «Об организации розничной торговли». 2 декабря, 1925 // ГАНИСО. - Ф. 27. - Оп. 1. - Д. 52.

27. Резолюция Пленума Самарского губкома РКП(б) «Об итогах хлебозаготовительной компании». 5 декабря, 1925 // ЦДНИСО. -Ф. П-1. -Оп. 1. Д. 1552.

28. Сабгайда, В. Г. Реорганизация Госрыбтреста и интересы местного края / В. Г. Сабгайда // Наш край. - Астрахань, 1925. - № 6. - С. 22-46.

29. Сводка Информационного отдела ЦК РКП(б) от 30 ноября, 1925 // Российский государственный архив социально-политической истории (РГАСПИ). - Ф. 17. - ОП. 13. - Д. 53.

30. Сводки из сообщений секретарей губкомов в Информационный отдел ЦК РКП(б) от 15 октября, 1924 // РГАСПИ. - Ф. 17. - ОП. 32. - Д. 15.

31. Сводки из сообщений секретарей губкомов в Информационный отдел ЦК РКП(б) от 15 апреля, 1925 // РГАСПИ. - Ф. 17. - ОП. 32. - Д. 4.

32. XVII Саратовская губернская конференция РКП(б). 17-18 декабря, 1925 // Государственный архив новейшей истории Саратовской области (ГАНИСО). - Ф. 27. - ОП. 3. - Д. 509.

33. Те-Ге. Началась путина / Те-Ге // Коммунист. - Астрахань, 1925. - 11 апр.

34. Тезисы к Пленуму Саратовского губернского комитета РКП(б) «Сущность переустройства крестьянских хозяйств и способы его осуществления в Саратовской губернии». 19 мая, 1925 // ГАНИСО. - Ф. 27. - Оп. 8. - Д. 91.

35. Телеграмма А.И. Микояна от 6 ноября, 1927 // ЦДНИСО. - Ф. П-1. - ОП. 1. - Д. 2558.

36. Шишкин, В. А. Россия в годы «Великого перелома» в восприятии иностранного дипломата (1925-1931 гг.) / В. А. Шишкин. - СПб. : Дмитрий Буланин, 1999. - 285 с.

37. Эрлих, А. Дискуссии об индустриализации в СССР. 1924-1928 / А. Эрлих. - М. : Дело, 2010. $248 \mathrm{c}$.

\section{REFERENCES}

1. Baskin G.I. Sovremennaya differentsiatsiya i sovremennye tipy krestyanskikh khozyaystv [Modern Differentiation and Modern Types of Peasant Farms]. Vestnik Srednego Povolzhya, 1926, no. 1, p. 136.

2. Batrashev D.K. Chastnoe predprinimatelstvo $\mathrm{v}$ gody novoy ekonomicheskoy politiki $\mathrm{V}$ Astrakhanskoy gubernii (okruge) v 1921-1929 gg. [Private Business in the Years of the New Economic Policy in the Astrakhan Province in 1921-1929]. 
Alternativy bolshevistskoy modernizatsii v gody novoy ekonomicheskoy politiki [Alternatives to Bolshevik Modernization in the Years of the New Economic Policy]. Moscow, ANO NII «Istorii, ekonomiki i prava» Publ., 2014, pp. 77-93.

3. Valentinov N. (Volskiy N.). Novaya ekonomicheskaya politika i krizis partii posle smerti Lenina. Gody raboty $v$ VSNKh vo vremya NEP. Vospominaniya [New Economic Policy and Crisis of the Party after Lenin's Death. Years of Work in the Supreme Council of National Economy during the NEP. Memoirs]. Moscow, Sovremennik Publ., 1991. 367 p.

4. Dekret Soveta narodnykh komissarov RSFSR. 31 maya 1921. «O rybnoy promyshlennosti i rybolovstve» [Decree of the Council of People's Commissars of the RSFSR. May 31, 1921. "On the Fishing Industry and Fishery"]. Muzey istorii Rossiyskikh reform imeni P.A. Stolypina [Museum of the History of Russian Reforms named after P.A. Stolypin]. URL: http://muzejreform.rf/node/13795. (accessed March 14, 2017).

5. Zhukov Yu. Oborotnaya storona NEPa. Ekonomika i politicheskaya borba v SSSR. 1923$1925 \mathrm{gg}$. [The Reverse Side of the NEP. Economics and Political Struggle in the USSR. 1923-1925]. Moscow, Akva-Term Publ., 2014. 448 p.

6. Zenchenko T. Myasnoy rynok Astrakhanskoy gubernii [Meat Market of the Astrakhan Province]. Nash Kray, 1925, no. 3, pp.61-72.

7. Informatsionnaya spravka Narkomata vnutrenney torgovli SSSR ot 10 noyabrya, 1925 [Information Reference of the People's Commissariat of Internal Trade of the USSR of November 10, 1925]. Rossiyskiy gosudarstvennyy arkhiv ekonomiki [Russian State Archive of Economics], F. 4372, Op. 12, D. 19.

8. Kisilevich K.S. K voprosu o vosstanovlenii lovetskogo khozyaystva [On the Restoration of Farming Economy]. Nash Kray, 1924, no. 1, pp. 44-45.

9. Kogan G.A. Byudzhet saratovskogo rabochego [The Budget of the Saratov Worker]. Nizhnee Povolzhye, 1924, no. 1, p. 38.

10. Kodin E.V. «Smolenskiy naryv» ["Smolenskiy Abscess"]. Smolensk, SGPI Publ., 1995. 112 p.

11. Kochakov A.F. Potrebitelskaya kooperatsiya v Samarskoy gubernii [Consumer Cooperation in the Samara Province]. Vestnik Srednego Povolzhya, 1925, no. 4, pp. 46-47.

12. Landrikov G. «Gore-kooperatory» [WoeCooperators]. Kommunist, 1926, 12 October.

13. Larionov A. Dinamika torgovykh predpriyatiy za 1923/24 i 1924/25 khozyaystvennyy god v Astrakhanskoy gubernii po dannym promnaloga [Dynamics of Trade Enterprises for 1923/24 and 1924/ 25 Economic Year in the Astrakhan Province according to the Data of Industrial Plan]. Nash Kray, 1926, no. 910, pp. 32-38.
14. Lupikin V.I. Torgovlya. Obzor za 1922/23 khozyaystvennyy god [Trade. Review for the 1922/23 Economic Year]. Nash Kray, 1924, no. 2, pp. 72-91.

15. Papsueva V.N., ed. Na yuzhnom forposte Rossii. Iz istorii Upravleniya Federalnoy sluzhby bezopasnosti RF po Astrakhanskoy oblasti. 19182000 gg.: Dokumenty. Materialy. Vospominaniya [At the Southern Forepost of Russia. From the History of the Office of the Federal Security Service of Russia in the Astrakhan Region. 1918-2000: Documents. Materials. Memories]. Volgograd, Stanica-2 Publ., 2000. $321 \mathrm{p}$.

16. NEP: vzglyad so storony [NEP: a Side View]. Moscow, Moskovskiy rabochiy Publ., 1991. 303 p.

17. Pavlyuchenkov S.A. "Orden mechenostsev»: partiya $i$ vlast posle revolyutsii. 1917-1929 [“Order of the Sword Bearers": Party and Power after the Revolution. 1917-1929]. Moscow, Sobranie Publ., 2008. 463 p.

18. Pavlyuchenkov S.A. S chego nachinalsya nep [Where did the NEP Begin?]. Trudnye voprosy istorii [The Difficult Questions of History]. Moscow, Politizdat Publ., 1991, pp. 45-61.

19. Potyaev A.I. Volgo-Kaspiyskaya rybnaya promyshlennost [Volga-Caspian Fishery Industry]. Byulleten rybnogo khozyaystva, 1928, no. 11, p. 15.

20. Preobrazhenskiy E. Osnovnoy zakon sotsialisticheskogo nakopleniya [The Main Law of Socialist Accumulation]. Puti razvitiya: diskussii 1920-kh gg.: sb. st. [Ways of Development: Discussions of the 1920s. Collected Articles]. Leningrad, 1990, pp. 53-131.

21. XV Astrakhanskaya Gubernskaya konferentsiya VKP(b). 26-27 noyabrya, 1926 [XV Astrakhan Provincial Conference of the CPSU (b). November 26-27, 1926]. Gosudarstvennyy arkhiv sovremennoy dokumentatsii Astrakhanskoy oblasti [State Archive of Modern Documentation of the Astrakhan Region], F. 1, Op. 1, D. 172.

22. Razin A. Chastnyy kapital v tovarooborote i promyshlennosti Astrakhanskoy gubernii [Private Capital in the Trade Turnover and Industry of the Astrakhan Province]. Nash Kray, 1926, no. 8, pp. 24-33.

23. Rezolyutsiya Byuro Astrakhanskogo gubkoma $\mathrm{RKP}(\mathrm{b})$ «Ob itogakh vesenney putiny». 8 iyunya, 1925 [Resolution of the Bureau of the Astrakhan Provincial Gubernia Committee of the RCP(b) "On the Results of the Spring Way". June 8, 1925]. Gosudarstvennyy arkhiv sovremennoy dokumentatsii Astrakhanskoy oblasti [State Archive of Modern Documentation of the Astrakhan Region], F. 1, Op. 1, D. 176.

24. Rezolyutsiya Byuro Samarskogo gubkoma RKP(b) «O khlebozagotovkakh». 21 yanvarya, 1926 [Resolution of the Bureau of the Samara Gubernia Committee of the RCP (b) "On grain Procurements". January 21, 1926]. Tsentr dokumentatsii noveyshey istorii Samarskoy oblasti [Center for Documentation 
of Contemporary History of the Samara Region], F. P-1, Op. 1, D. 1869.

25. Rezolyutsiya Byuro Saratovskogo gubkoma RKP(b) «Itogi vyborov selskikh sovetov». 22 dekabrya, 1924 [Resolution of the Bureau of the Saratov Gubernia Committee of the RCP (B) "Results of the Election of Rural Councils". December 22, 1924]. Gosudarstvennyy arkhiv noveyshey istorii Saratovskoy oblasti [State Archive of Contemporary History of the Saratov Region], F. 27, Op. 1, D. 101.

26. Rezolyutsiya Byuro Saratovskogo gubkoma $\mathrm{RKP}(\mathrm{b})$ «Ob organizatsii roznichnoy torgovli». 2 dekabrya, 1925 [Resolution of the Bureau of the Saratov Gubernia Committee of the RCP (B.) "On the Organization of Retail Trade". December 2, 1925]. Gosudarstvennyy arkhiv noveyshey istorii Saratovskoy oblasti [State Archive of Contemporary History of the Saratov Region], F. 27, Op. 1, D. 52.

27. Rezolyutsiya Plenuma Samarskogo gubkoma $\mathrm{RKP}(\mathrm{b})$ «Ob itogakh khlebozagotovitelnoy kompanii». 5 dekabrya, 1925 [Resolution of the Plenum of the Samara Gubernia Committee of the RCP(B) "On the Results of the Grain-Making Company”. December 5, 1925]. Tsentr dokumentatsii noveyshey istorii Samarskoy oblasti [Center for Documentation of Contemporary History of the Samara Region], F. P-1, Op. 1, D. 1552.

28. Sabgayda V.G. Reorganizatsiya Gosrybtresta i interesy mestnogo kraya [Reorganization of State Fisfery Trust and the Interests of the Local Outskirts]. Nash Kray, 1925, no. 6, pp. 22-46.

29. Svodka Informatsionnogo otdela TsK RKP(b) ot 30 noyabrya, 1925 [Summary of the Information Department of the Central Committee of the RCP(b) of November 30, 1925]. Rossiyskiy gosudarstvennyy arkhiv sotsialno-politicheskoy istorii [Russian State Archive of Social and Political History], F. 17. Op. 13. D. 53.

30. Svodki iz soobshcheniy sekretarey gubkomov v Informatsionnyy otdel TsK RKP(b) ot 15 oktyabrya, 1924 [Summaries from Secretaries of the Provincial Gubernia to the Information Department of the Central Committee of the RCP(b) of October 15,
1924]. Rossiyskiy gosudarstvennyy arkhiv sotsialnopoliticheskoy istorii [Russian State Archive of Social and Political History], F. 17, Op. 32, D. 15.

31. Svodki iz soobshcheniy sekretarey gubkomov v Informatsionnyy otdel TsK RKP(b) ot 15 aprelya, 1925 [Summaries from Secretaries of the Provincial Gubernia to the Information Department of the Central Committee of the RCP(b) OfApril 15, 1925]. Rossiyskiy gosudarstvennyy arkhiv sotsialnopoliticheskoy istorii [Russian State Archive of Social and Political History], F. 17, Op. 32, D. 4.

32. XVII Saratovskaya gubernskaya konferentsiya RKP(b). 17-18 dekabrya, 1925 [XVII Saratov Gubernia Conference of the RCP (b). December 17-18, 1925]. Gosudarstvennyy arkhiv noveyshey istorii Saratovskoy oblasti [State Archive of Contemporary History of the Saratov Region], F. 27, Op. 3, D. 509.

33. Te-Ge. Nachalas putina [The Way Began]. Kommunist, 1925, 11 April.

34. Tezisy k Plenumu Saratovskogo gubernskogo komiteta RKP(b) «Sushchnost pereustroytva krestyanskikh khozyaystv i sposoby ego osushchestvleniya v Saratovskoy gubernii». 19 maya, 1925 [Theses to the Plenum of the Saratov Gubernia Committee of the RCP (B.) "The Essence of the Reorganization of Peasant Farms and the Ways of Its Implementation in the Saratov Gubernia." May 19, 1925]. Gosudarstvennyy arkhiv noveyshey istorii Saratovskoy oblasti [State Archive of Contemporary History of the Saratov Region], F. 27, Op. 8, D. 91.

35. Telegramma A.I. Mikoyana ot 6 noyabrya, 1927 [A.I. Mikoyan's Telegram of November 6, 1927]. Tsentr dokumentatsii noveyshey istorii Samarskoy oblasti [Center for Documentation of Contemporary History of the Samara Region], F. P-1, Op. 1, D. 2558.

36. Shishkin V.A. Rossiya v gody «Velikogo pereloma» $v$ vospriyatii inostrannogo diplomata (1925-1931 gg.) [Russia during the Great Break in the Perception of a Foreign Diplomat (1925-1931)]. Saint Petersburg, Dmitriy Bulanin Publ., 1999. 285 p.

37. Erlikh A. Diskussii ob industrializatsii v SSSR. 1924-1928 [Discussions on Industrialization in the USSR. 1924-1928]. Moscow, Delo Publ., 2010. 248 p.

\section{Information about the Authors}

Sergey V. Vinogradov, Doctor of Sciences (History), Professor, Head of the Center for Research of the Lower Volga region history in the Soviet period, Astrakhan State University, Tatishcheva St., 20A, 414056 Astrakhan, Russian Federation, vinogradov-7@yandex.ru, http://orcid.org/0000-0002-6601-4363

Yuliya G. Eshchenko, Candidate of Sciences (History), Senior Researcher, Center for Research of the Lower Volga region history in the Soviet period, Astrakhan State University, Tatishcheva St., 20A, 414056 Astrakhan, Russian Federation, pushistik_yuliya@mail.ru, http://orcid.org/0000-0002-1207-327X

Nataliya I. Kulakova, Candidate of Sciences (History), Associate Professor, Department of History of Russia, Astrakhan State University, Tatishcheva St., 20A, 414056 Astrakhan, Russian Federation, volna1986@yandex.ru, http://orcid.org/0000-0002-0363-2797 


\section{Информация об авторах}

Сергей Вадимович Виноградов, доктор исторических наук, профессор, руководитель Центра изучения истории Нижнего Поволжья советского периода, Астраханский государственный университет, ул. Татищева, 20A, 414056 г. Астрахань, Российская Федерация, vinogradov7@yandex.ru, http://orcid.org/0000-0002-6601-4363

Юлия Геннадьевна Ещенко, кандидат исторических наук, старший научный сотрудник Центра изучения истории Нижнего Поволжья советского периода, Астраханский государственный университет, ул. Татищева, 20A, 414056 г. Астрахань, Российская Федерация, pushistik_yuliya@mail.ru, http://orcid.org/0000-0002-1207-327X

Наталия Игоревна Кулакова, кандидат исторических наук, доцент кафедры истории России, Астраханский государственный университет, ул. Татищева, 20A, 414056 г. Астрахань, Российская Федерация, vol-na1986@yandex.ru, http://orcid.org/00000-0002-0363-2797 